\title{
The effect of competitive intelligence on competitive strategy and performance: study on cafes and restaurants in Malang, Indonesia
}

\author{
Asminah Rachmi ${ }^{1}$ and Diana Eka Poernamawati ${ }^{1}$ \\ ${ }^{1}$ Department of Business Administration, State Polytechnic of Malang, Indonesia
}

\begin{abstract}
This study aims to investigate the effect of competitive intelligence to competitive strategy and performance of cafes and restaurant in Malang, Indonesia. Data analysis applying path analysis on 100 samples showed that competitive intelligence directly affects performance and indirectly through competitive strategy performance. These findings are expected to provide recommendations for strategic planning development efforts in the future for cafes and restaurants in Malang, and also to help in developing the best practices in responding the market change.
\end{abstract}

\section{INTRODUCTION}

Today's highly dynamic business environments have created risks to the survival of any enterprise (Schmitt, 2003). Therefore, strategic planning is an essential ingredient for enterprise business success in today's competitive environment (Cooper, 2001). For large corporations that have internal departments dedicated to provide the enterprise with economic data, market trends and competitive intelligence, they can manage the risks to survive and apply business strategies that increase their performance. There is empirical research that has shown the importance of strategic planning in providing insights into overcoming barriers and biases associated with failure of an enterprise (D. Miller, Hope, Eisenstat, Foote, \& Galbraith, 2002; Perry, 2001).

One of the most popular business strategies is competitive strategy developed by Porter (1980). The competitive strategy has been confirmed determines company's performance (Julien \& Ramangalahy, 2003) and the role of competitive intelligence is supporting competitive strategy by providing better information of external environment (Ma, 2000)

Cafes and restaurants businesses in Malang have been developed vastly (Fitriya, 2015). The trigger of cafe business development caused by the changing of society's life style especially for young people who like to spend their leisure time with their friends in cafes (Fimela, 2014). The increase in number of cafes and restaurants in Malang has created a tight competition and each of them should have strategies to compete and to exist in the market (Mazda, 2019). The objective of this research is to provide evidence for the capability of competitive intelligence to influence company's performance through competitive strategy of cafes and restaurants in Malang.

\section{LITERATURE REVIEW AND HYPOTHESES DEVELOPMENT}

\section{Competitive intelligence}

Competitive intelligence was popular in 1990s and becoming focus interest in strategic management (Reginald, 2000). Competitive intelligence is a way in gaining and using information about event and trend in the external environment (Matthews, 1990). Porter (1980, 1985, 1990, 1992, 2001) comprises the source of competitive intelligence into five forces that should be considered in industries analysis namely new entrant threat, substitution threat, bargaining power of supplier, bargaining power of customer and competition intensity. To win the competition, companies collected all information related to external environment such as competitors, customer, suppliers and market. That information 
showed the changing in the environment and finally determined strategies to respond those changing.

\section{Competitive strategy}

Porter (1980) defined competitive strategy as a combined target searched by companies and policies to find a way to arrive there. This strategy focused on competitive positioning that differentiate it from other competitors and added value through combined activities that were differ from competitors. Porter's (1980) competitive strategy based on three generic strategies used by companies namely differentiation, low cost and focus. Differentiation strategy usually is adopted to develop a unique product that is valued and searched by customers who want to be better compared or different to others. Low cost strategy targets a large market and emphasizes low production costs and with a certain level of product quality. Cost leadership is the clearest strategy with limited choices in which companies sell their products at an average industry price to gain market share (Peteraf, 1993). Focus strategy serves customers in narrower segments to achieve cost advantage or differentiation. Companies that choose Focus strategy enjoy the benefits of customers who have high loyalty, thereby suppressing competition among competitors (Porter, 1980, 1985, 1990, 2001).

\section{Company performance}

Company performance is a function of mutual influence between the company's competitive strengths with actions taken that enable the company to adapt to the external environment(A. Miller \& Dess, 1996). The objective approach is related to performance appraisal using absolute value while the perception approach is related to the assessment criteria by asking respondents their expectations and satisfaction as stakeholders. Previous studies that have used both approaches find a strong correlation between the two and have concluded that it is better to use perception measures if objective measurements are not available (Knights \& McCabe, 1997).

Most of the normative literature findings conclude that the value of Competitive Strategy depends on the enterprise's interpretation of Competitive Intelligence
(Matthews, 1990). There is evidence that competitive intelligence support competitive strategy (Ma, 2000).

H1: Competitive intelligence has positive effect on competitive strategy.

Previous research showed that competitive intelligence has direct on company performance. Tahmasebifard (2018) argues that firms may achieve superior market performance via exploiting Competitive Intelligence activities. Adidam, Banerjee and Shukla (2012) claim that competitive intelligence has effect on company performance.

H2: Competitive intelligence has positive effect on company performance.

Beside the direct impact of competitive intelligence to company performance, competitive strategy can play the role as mediator between them. Ferrier (2001) argues that competitive intelligence activities enable executive management teams to make reliable strategic decisions and actions aimed for enhancing the competitiveness and overall performance of a firm. Furthermore, Julien dan Ramangalahy (2003) claims that competitive strategies determine the performance of exporters of SMEs.

H3: Competitive Intelligence has a positive impact on competitive strategy which indirectly has a positive effect on company performance.

\section{METHODS}

In this research framework, the concept of competitive intelligence $(\mathrm{Cl})$ represents five variables namely $\mathrm{X} 1$ (the threat of new competitors), X2 (threat of substitute products), X3 (bargaining power of supplier), X4 (bargaining power of customers) and X5 (intensity of competition). Those variables affect performance (X9) both directly and indirectly through competitive strategy (CS) that represent three variables including $\mathrm{X} 6$ (differentiation strategy), X7 (low cost strategy) and $X 8$ (focus strategy). The items used to measure competitive intelligence and competitive strategy variables are developed from Porter's theory (Porter, $1980,1985,1990,2001)$ and items used to 
measure performance are developed from Keegan, Huemann, and Turner (2012)

This research uses quantitative method for testing theory by examining the relationships between variables (Creswell, 2013). The survey technique is used to get specific information quickly through questionnaire answers from the target group (Kumar, 2005). Data analysis for this study used Path Analysis which is a further analysis of regression analysis. Steiner (2005) claimed that path analysis is an extension of multiple linear regression and which shows the analysis of complex models.

The population is cafes and restaurants in Malang. Based on data collected by Tripadvisor (2017) there were 391 cafes and restaurants in the city of Malang. Since the factor analysis requires a minimum of 100 data (Tabachnick \& Fidell, 2007) then the total sample was rounded to 100 respondents. The sampling technique used was purposive sampling that needs consideration (Sugiyono, 2015) The selected sample was cafes and restaurants that had been established for at least one year so that company performance could be measured.

\section{RESULT AND DISCUSSION}

The conceptual model developed for this research is shown on Figure 1 below.

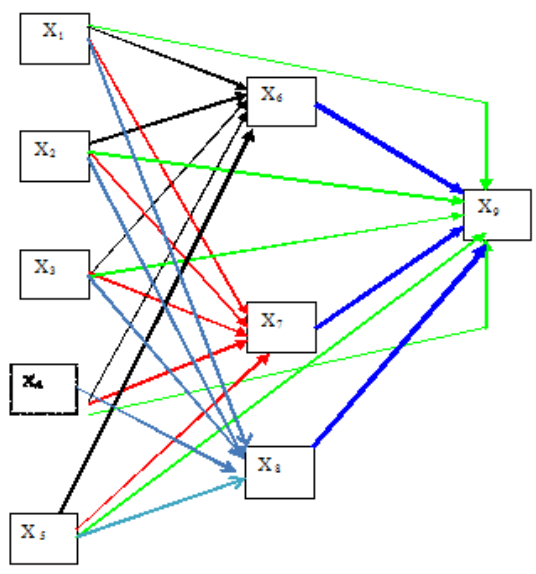

Figure 1.

Conceptual model
Based on the diagram in Figure 1, there were 5 regression blocks with the regression equation as below:

Regression Block-1 (black lines)

$\mathrm{X} 6=\mathrm{p} 61 \mathrm{X} 1+\mathrm{p} 62 \mathrm{X} 2+\mathrm{p} 63 \mathrm{X} 3+\mathrm{p} 64 \mathrm{X} 4+$ $p 65 \times 5+p 6 R$

Regression Block-2 (red lines)

$\mathrm{X} 7=\mathrm{p} 71 \mathrm{X} 1+\mathrm{p} 72 \mathrm{X} 2+\mathrm{p} 73 \mathrm{X} 3+\mathrm{p} 74 \mathrm{X} 4+$ $\mathrm{p} 75 \times 5+\mathrm{p} 7 \mathrm{~S}$

Regression Block-3 (blue lines)

$\mathrm{X} 8=\mathrm{p} 81 \mathrm{X} 1+\mathrm{p} 82 \mathrm{X} 2+\mathrm{p} 83 \mathrm{X} 3+\mathrm{p} 84 \mathrm{X} 4+$ $\mathrm{p} 85 \times 5+\mathrm{p} 8 \mathrm{~T}$

Regression Block -4 (green lines)

$\mathrm{X} 9=\mathrm{p} 91 \mathrm{X} 1+\mathrm{p} 92 \mathrm{X} 2+\mathrm{p} 93 \mathrm{X} 3+\mathrm{p} 94 \mathrm{X} 4+$ p95X5 + p9U

Regression Block -5 (green and blue bold lines)

$\mathrm{X} 9=\mathrm{p} 91 \mathrm{X} 1+\mathrm{p} 92 \mathrm{X} 2+\mathrm{p} 93 \mathrm{X} 3+\mathrm{p} 94 \mathrm{X} 4+$ $p 95 X 5+p 96 X 6+p 97 X 7+p 98 X 8+p 9 U$

The results of regression analysis for each block showe that in Regression Block 1 , the variables which had sig. $<0.05$ were X4 (0.016) and X5 (0.002). In Regression Block -2 , the variables which had sig. $<0.05$ were X1 (0.042) and X5 (0.006). In Regression Block -3 , the variables which had sig. $<0.05$ were X2 $(0.032)$ and X5 (0.003). In Regression Block-4, the variables which had sig. $<0.05$ were X1 (0.049), X2 (0.002) and X4 (0.043). In Regression Block -5 , the variables which had sig. $<0.05$ were X4 (0.029) and X6 (0.014).

\section{Hypothesis testing}

In testing hypotheses, $\mathrm{HO}$ is rejected if the $\mathrm{p}$ value for the $t$-statistic (the significance of the above $t$ ) is less than 0.05 . Rejection of $\mathrm{HO}$ means the path coefficient in question is meaningful. The acceptance of hypothesis $\mathrm{H} 1$ was shown from Regression Block - 1 which had two significant paths (X4 and X5), Block-2 which had two significant paths (X1 and $X 5)$, and Block-3 which had two significant paths (X2 and X5).

The acceptance of hypothesis $\mathrm{H} 2$ was shown from Regression Block -4 which had three significant paths (X1, X2 and X4). The acceptance of hypothesis $\mathrm{H} 3$ was shown from Regression Block -5 which had two significant paths (X4 and $\mathrm{X} 6$ ). 


\section{Discussion}

The study findings confirmed significant and positive impact of implementation of Competitive Intelligence on Competitive Strategy and performance of companies in marketplace.

The impact of competitive intelligence on competitive strategy as stated in Hypothesis $1(\mathrm{H} 1)$ was shown in the results of regression block-1, block-2 and block 3 . The bargaining power of customers and the intensity of competition significantly influenced differentiation strategy. The majority of cafes and restaurants in the city of Malang consider that a differentiation strategy needs to be done when customers have many food choices at home or outside the home. Differentiation strategy is also used to anticipate the high intensity of competition in terms of offering a variety of foods and a comfortable atmosphere for customers. Although this comes with a high price but by targeting the upper middle-class customers who have high taste, this strategy can be successful.

Components of competitive intelligence such as the threat of new competitors and the intensity of competition also significantly influenced the low-cost strategy. Low cost strategy is applied by cafe and restaurant entrepreneurs to anticipate the emergence of new competitors with the same food menu or maybe more varied at competitive prices. New cafes and restaurants usually offer promo prices to attract consumers. The intensity of competition allows cafes and restaurants to compete at the level of price and variety of food. Low cost strategy can be done by reducing operational costs by finding suppliers of cheap raw materials or employing employees with lower wages. On the other hand, the threat of substitution product and competition intensity significantly influenced the focus strategy. The threat of substitute products is substitute food provided by cafes or other restaurants with the same category. Cafe and restaurant entrepreneurs can use a focus strategy by targeting consumers or loyal customers. Focus strategy can also be used to anticipate the high intensity of competition. By making good communication and satisfying service to loyal customers, this strategy allows cafes and restaurants to survive in the intense competition.
The acceptance of $\mathrm{H} 1$ supports the previous research conducted by Trim and Lee (2008) that gathering intelligence is necessary for strategic planning. Following analysis by Porter (1980, 1985, 1990, 1992, 2001), the relationship between Competitive Intelligence and Competitive Strategy has been confirmed.

The $2^{\text {nd }}$ hypothesis that states competitive intelligence has positive impact on company performance is accepted based on the result of regression block 4 . The threat of new competitors, the threat of substitute products, and consumer bargaining significantly affected performance. Cafe and restaurant in Malang need to anticipate the threat of new competitors, the threat of substitute products and consumer bargaining to increase their performance. According to Tahmasebifard (2018) in the current economic recession in which companies are wrestled down with cutting their cost and performing in most efficient state, they must know which subtype of competitive intelligence that has the greater impact on the performance. Gračanin, Kalac, and Jovanović (2015) claim that companies must further explore benefits emerging from Competitive Intelligence activities in order to improve their business performances,

The acceptance of $\mathrm{H} 3$ that Competitive Intelligence has a positive on Competitive Strategies which indirectly has a positive effect on company performance is shown on the results of the block-5 regression analysis. The bargaining power of customers seemed influenced the differentiation strategy that indirectly influenced performance. Differentiation strategy allows restaurant entrepreneurs to provide a unique and interesting menu and a cozy cafe / restaurant atmosphere that will make customers interested in trying food and enjoying a comfortable atmosphere. This result support previous research conducted by Brown and Blackmon (2005) who claim that the implementation of a competitive strategy should be linked to market requirements to enable the firm to achieve superior performance. Furthermore, the literature discussions on the process of strategic planning support the relationship between $\mathrm{Cl}, \mathrm{CS}$ and performance (Ardekani \& Nystrom, 1993). 


\section{CONCLUSION}

Through completion with path analysis, the results of the block- 1 to block-5 regression analysis it was shown that not all components of competitive intelligence influenced the selection of competitive strategies and performance. In relation to the influence of competitive intelligence on competitive strategies, it turned out that only the bargaining power of consumers and the intensity of competition affected the selection of Differentiation strategy, while the threat of new competitors and the intensity of competition affected the selection of Low Cost strategy, while the threat of substitute products and the intensity of competition affected the choice of focus strategy. Furthermore, regarding the influence of competitive intelligence to performance, the results of the analysis showed that the threat of new competitors, the threat of substitute products, and consumer bargaining power significantly affected performance. On the other side, the indirect effect of competitive intelligence through competitive strategies on performance was shown by the significant influence of differentiation strategy to performance.

Competitive intelligence becomes important for companies in the current era because of rapid technological changes that is followed by changes in consumer tastes towards goods and services. Competitive intelligence is to help to identify and to assess business risks and opportunities so that business risks can be avoided and opportunities can be taken advantage of. Companies that function competitive intelligence will benefit from the competition because they can use appropriate strategies to solve internal problems or face competition and business challenges. The results of this study provide several findings related to strategic planning and company performance. The strategic planning process is focused on the relationship between competitive intelligence, competitive strategy and company performance.

\section{REFERENCES}

Adidam, Phani Tej, Banerjee, Madhumita, \& Shukla, Paurav. (2012). Competitive Intelligence and Firm Performance In Emerging Market: An Exploratory Study in India. Journal of Business and Industrial Marketing, 27(3), 242-254.

Ardekani, Y. M., \& Nystrom, P. C. (1993). Designs for Environmental Scanning System: Tests of Contingency Theory. Working Paper. University of Wisconsin Milwaukee.

Brown, S., \& Blackmon, K. (2005). Aligning manufacturing strategy and businesslevel competitive strategy in new competitive environments: the case for strategic resonance. Journal of Management Studies, 42, 793-816.

Cooper, J. (2001). Enhancing the Competitive Success of Canadian SMEs. CMA Management(Jul/Aug), 16-21.

Creswell, John W. (2013). Research Design: Pendekatan Kualitatif, Kuantitatif, dan Mixed (3rd Ed.). Yogyakarta: Pustaka Pelajar.

Ferrier, W. (2001). Navigating the competitive landscape; the drivers and consequences of competitive aggressiveness. Academy of Management Journal,, 44, 858-877.

Fimela. (2014). D'Flavors Cafe \& Resto Malang, Tempat Hangout Yang Beri Kesan Klasik. Retrieved 19 June 2020, from https://www.fimela.com/lifestylerelationship/read/3741030/dflavorscafe-amp-resto-malang-tempathangout-yang-beri-kesan-klasik

Fitriya, Devita Triyana. (2015). Pengawasan Dinas Pendapatan Daerah Kota Malang terkait Penagihan Pajak Restoran di Kota Malang (Studi Implementasi Peraturan Daerah Kota Malang Nomor 16 Tahun 2010 Tentang Pajak Daerah). Artikel IImiah. Law Department. Universitas Brawijaya.

Gračanin, Šaban , Kalac, Edin , \& Jovanović, Dejan (2015). Competitive Intelligence: Importance and Application in Practice. Review of Innovation and Competitiveness, 1(1), 25-44.

Julien, Pierre Andre, \& Ramangalahy, Charles. (2003). Competitive Strategy and Performance of Exporting SMEs: An Empirical Investigation of The Impact of Their Export Information Search and Competencies. Entrepreneurship Theory and Practice(spring), 227-245.

Keegan, Anne, Huemann, Martina, \& Turner, J. Rodney. (2012). Beyond the line: exploring the HRM responsibilities of line managers, project managers and the HRM department in four projectoriented companies in the Netherlands, Austria, the UK and the USA. The 
International Journal of Human resource Management, 23(15), 3085-3104.

Knights, D., \& McCabe, G. (1997). How would you measure something like that Quality in a Retail Bank. Journal of Management Studies, 34, 371-388.

Kumar, R. (2005). Research methodology: a step-by-step guide for beginners (2nd ed.). Frenchs Forest, NSW: Pearson Longman.

Ma, Hao. (2000). Of Competitive Advantage: Kinetic and Positional. Business Horizons, 43(1), 53-64.

Matthews, Charles H. (1990). Small Firm Strategic Planning: Strategy, Environment and Performance (Information \& Service., Trans.): University Microfilms International,.

Mazda, Gigih. (2019). Kafe di Malang yang Tumbuh dan Tumbang. Retrieved 17 June, 2020, from https://kumparan.com/tugumalang/kafedi-malang-yang-tumbuh-dan-tumbang1551768038570428054/full

Miller, A., \& Dess, G. (1996). Strategic Management (2nd ed.). New York: McGraw Hill.

Miller, D. , Hope, Eisenstat, R., Foote, N., \& Galbraith, J. (2002). The Problem of Solutions. Business Horizon, 45(2), 312.

Perry, S. (2001). The Relationship Between Written Business Plans and the Failure of Small Businesses in the U.S. Journal of Small Business Management(July), 201-208.

Peteraf, Margaret A. (1993). The Cornerstones of Competitive Advantage: A ResourceBased View. Strategic Management Journal, 14, 179-191.

Porter, M. E. (1980). Competitive Strategy: Techniques for Analyzing Industries and Competitors. New York: Free Press.

Porter, M. E. (1985). Competitive Advantage: Creating and Sustaining Superior Performance. New York: Free Press,.

Porter, M. E. (1990). The Competitive Advantage of Nations. London: Macmillan,.

Porter, M. E. (1992). What is Strategy. Harvard Business Review, 96(Nov/Dec), 61-78.

Porter, M. E. (2001). Strategy and the Internet. Harvard Business Review(March), 6278.

Reginald, M. B. (2000). Competing effectively: Environmental Scanning, Competitive
Strategy, and Organizational Performance in Small Manufacturing Firms. Journal of Small Business Management, 38(1), 27-47.

Schmitt, B. (2003). Customer Experience Management. New York: The Free Press.

Steiner, David L. (2005). Finding Our Way: An Introduction to Path Analysis. Canadian Journal of Psychiatry, 50(2).

Sugiyono. (2015). Statistika untuk Penelitian. Bandung: CV Alfabeta.

Tabachnick, Barbara G., \& Fidell, Linda S. (2007). using Multivariate Statistics (5th ed.). Boston: Pearson Education Inc.

Tahmasebifard, Hamid (2018). The role of competitive intelligence and its subtypes on achieving market performance. Cogent Business \& Management, 5(1540073), 1-16.

Trim, P. R. J. , \& Lee, Y. I. (2008). A strategic marketing intelligence and multiorganisational resilience framework. European Journal of Marketing,, 42(78), 786-803.

Tripadvisor. (2017, 17 January 2017). Restoran di Malang. Retrieved 20 January, 2017, from https://www.tripadvisor.co.id/ Restaurants-g297710-Malang East_Java_Java.html 